\title{
KONDISI LINGKUNGAN, PERILAKU HIDUP SEHAT, DAN STATUS KESEHATAN KELUARGA WANITA PEMETIK TEH
}

\author{
(Environmental Condition, Healthy Life Behaviour, and Health Status of Women Tea Picker's \\ Family in PTPN VIII Pengalengan, Bandung, West J ava) \\ Yuli Fitriyani $^{1}$, Katrin Roosita ${ }^{2 *}$, dan Yekti Hartati ${ }^{2}$ \\ ${ }_{1}^{1}$ Program Studi Gizi Masyarakat dan Sumberdaya Keluarga, Fakultas Pertanian (FAPERTA) IPB. \\ 2 Departemen Gizi Masyarakat, Fakultas Ekologi Manusia (FEMA), IPB \\ Tel: 0251-8628304/8621258; Fax: 0251-8625846/8622276
}

\begin{abstract}
ABST RACT
The aim of this research is to study environmental condition, healthy life behaviour, and health status of women tea picker's family in PTPN VIII Pengalengan, Bandung, West J ava. The cross sectional study design is used in this research and total number of samples are 92 family of women tea picker who live in Malabar Plantation. The inclusion criteria of the sample is having children 0-72 month age and willing to be interviewed. The place of the research was chosen purposively. Malabar Plantation was chosen from the other five plantations (clusters) because of its easier access and the homogenous characteristics of inter cluster. Primary data consists of family characteristics, environmental condition, healthy life behavior, and family's health status. Secondary data consists of general description of Malabar Plantation and Banjarsari Village. Data was processed and analyzed with descriptive statistic and inference, and correlation analysis used Rank Spearman correlation test. The results revealed that the family were live in average (moderate) environmental condition, and only a few families live in good environmental condition. Their family's health behaviour was good. The symptoms/kind of diseases which found among the samples were fever, acute respiratory infection (ARI) diseases, digestion organ diseases, skin disease, and hepatitis. Family's member who was the most susceptible to disease was children. The related factors to environmental condition of women tea picker's family were family income and family size. The water source used by the families, which was one of factors of the environmental condition's, was related to health status of women tea picker's family. The acute respiratory infection (ARI) disease and hepatitis cases in family were related to better water source for taking a bath, wash the dishes and wash hands after defecation. Better water source, then less cases of the diseases.
\end{abstract}

Keywords: environment, healthy life behavior, tea picker family, health status

\section{PENDAHULUAN}

Kesehatan adalah hak dasar tiap manusia dan merupakan salah satu faktor yang menentukan kualitas sumberdaya manusia. Perlu dilakukan upaya untuk memelihara dan meningkatkan kualitas kesehatan dari ancaman dan bahaya yang merugikan. Pemerintah melalui Visi Indonesia Sehat 2010, berupaya agar masyarakat dapat hidup dalam lingkungan dan perilaku sehat, mampu menjangkau pelayanan kesehatan yang bermutu, adil dan merata, sehingga memiliki derajat kesehatan yang setinggi-tingginya (BPS, 2002; Depkes, 1999).

* Penulis untuk korespondensi, Departemen Gizi Masyarakat, FEMA, IPB; Tel: 0251-8628304/8621258: Fax: 0251-8625846/8622276 Email: kroosita@yahoo.com
Keluarga merupakan unit kelompok terkecil dalam masyarakat. Status kesehatan keluarga berpengaruh terhadap status kesehatan masyarakat. Sebuah keluarga dikatakan sehat apabila setiap anggota dalam keluarga tersebut sehat, baik fisik, mental maupun sosialnya (Subandriyo, 1993).

Penyakit infeksi merupakan permasalahan kesehatan di Indonesia karena penyakit ini paling sering diderita berbagai kalangan masyarakat. Prevalensi penyakit infeksi sangat dipengaruhi oleh lingkungan baik fisik maupun biologik. Di antara berbagai penyakit infeksi, flu dan diare merupakan penyakit infeksi yang paling sering ditemukan. Penyakit infeksi masih menjadi penyebab kematian utama bayi dan balita terutama pada keluarga miskin. Prevalensi penyakit infeksi sepeti ISPA, diare, 
TBC, dan malaria sudah menurun, namun pada masyarakat miskin prevalensinya masih cukup tinggi (Sukarni, 1994; Depkes, 2005). Masyarakat yang tinggal di perkebunan teh di Jawa cenderung mengalami kesulitan memperoleh perumahan dan lingkungan permukiman yang sehat dan layak (Bapenas, 2004). Kelompok masyarakat ini memiliki fasilitas sanitasi yang kurang memadai. Kondisi lingkungan yang baik dapat berpengaruh positif terhadap terwujudnya status kesehatan yang baik, sebaliknya lingkungan yang buruk dapat memicu terjadinya berbagai penyakit terutama penyakit infeksi.

Penyakit yang cenderung dialami wanita pemetik teh adalah penyakit infeksi seperti infeksi saluran pencernaan (diare dan disentri) serta infeksi saluran pernafasan akut atas dan bawah (Wirakusumah, 1999). Penelitian lain yang dilakukan Basta et al. (1979), menunjukkan bahwa pekerja perkebunan cenderung mengalami penyakit infeksi akut dan kronis. Infeksi penyakit yang diderita meliputi influenza, pilek, diare, hepatitis, demam, tonsilitis, gastritis, tuberculosis, dan bronchitis.

Penelitian ini bertujuan untuk mengetahui kondisi lingkungan, perilaku hidup sehat, dan status kesehatan keluarga wanita pemetik teh di PTPN VIII Pengalengan, Bandung, Jawa Barat.

\section{METODE PENELITIAN}

\section{Desain, Tempat, dan Waktu Penelitian}

Penelitian ini merupakan penelitian cross sectional yang dilakukan di PTPN VIII Pengalengan, Kabupaten Bandung, Propinsi Jawa Barat. Pemilihan tempat dilakukan secara purposive dari lima wilayah perkebunan ("cluster area") yaitu Rancabali, Purbasari, Malabar, Talun Santosa, dan Sedep. Penelitian ini dilaksanakan pada bulan Maret sampai Juni 2008 yang meliputi pengumpulan, pengolahan serta analisis data.

\section{Penarikan Contoh}

Populasi contoh berjumlah 92 keluarga wanita pemetik teh yang tinggal di perkebunan Malabar. Contoh tersebut merupakan contoh yang sama dengan contoh penelitian sebelumnya oleh Sunarti, Roosita, dan Herawati (2007) yang dipilih secara acak (random sampling). Kriteria contoh pada penelitian ini sama dengan penelitian sebelumnya yaitu, wanita pemetik teh yang memiliki anak usia 0-72 bulan dan bersedia diwawancarai.

\section{」enis dan Cara Pengumpulan Data}

Jenis data yang dikumpulkan berupa data primer dan data sekunder. Data primer meliputi karakteristik keluarga (umur orang tua, pendidikan orang tua, pekerjaan orang tua, pendapatan keluarga, dan besar keluarga), kondisi lingkungan (kondisi fisik rumah, sumber air, dan sarana pembuangan limbah RT), perilaku hidup sehat (termasuk konsumsi suplemen dan tanaman obat), serta status kesehatan keluarga.

Data primer diperoleh dengan pengamatan dan wawancara langsung kepada responden dengan kuesioner terstruktur. Data sekunder meliputi profil PTPN VIII Unit Perkebunan Malabar serta data geografi dan demografi Desa Banjarsari. Data sekunder ini diperoleh dari kantor PTPN VIII Unit Perkebunan Malabar dan kantor kepala Desa Banjarsari, Kecamatan Pengalengan, Kabupaten Bandung, Propinsi Jawa Barat.

\section{Pengolahan dan Analisis Data}

Tahapan pengolahan data dimulai dari verifikasi, coding, entry, cleaning dan selanjutnya dianalisis. Umur orang tua dikategorikan berdasarkan pengkategorian usia dewasa WNPG (2004), yaitu usia dewasa muda (19-29 tahun), dewasa madya (30-49 tahun), dan dewasa lanjut (50-64 tahun). Tingkat pendidikan akhir orang tua dibedakan menjadi tidak sekolah, tidak tamat SD, tamat SD, tamat SMP, dan tamat SMA.

Pengkategorian keluarga miskin dan tidak miskin berdasarkan batas garis kemiskinan Kabupaten Bandung yaitu Rp. 186,774.00/kap/ bulan (BPS, 2006). Keluarga dengan pendapatan perkapita kurang dari Rp. 186,774.00/kap/ bulan termasuk kategori keluarga miskin, dan lebih dari atau sama dengan Rp. 186,774.00/ kap/bulan termasuk keluarga tidak miskin. Besar keluarga dibedakan menjadi keluarga kecil ( $\leq 4$ orang), sedang (5-7 orang), dan besar ( $\geq 8$ orang) berdasarkan Hurlock (1993).

Data kondisi lingkungan dinilai dengan menghitung skor total yang diperoleh. Kondisi lingkungan diukur melalui tiga hal yaitu kondisi fisik rumah, sumber air, dan sarana pembuangan limbah RT.

1. Kondisi fisik rumah dinilai menggunakan 13 pertanyaan mengenai jenis lantai, dinding, atap, ventilasi, jendela, curahan sinar matahari di pagi/siang hari, kepemilikan kamar mandi, tempat keluarga mandi dan kondisi kamar mandi, kepemilikan jamban, kepemilikan saluran pembuangan air lim- 
bah, keberadaan kandang ternak, dan luas ruangan per orang. Skoring jawaban setiap pertanyaan dengan rentang nilai antara 1 sampai 3, sehingga total skor minimum 13 dan maksimum 39.

2. Sumber air dinilai dengan 2 pertanyaan mengenai sumber air minum dan sumber air bersih yang digunakan untuk mandi/ mencuci dengan pilihan jawaban air hujan /air sungai, sumur/mata air, dan ledeng/ PAM. Bila menjawab air hujan/air sungai diberi skor 1, sumur/mata air diberi skor 2 , dan ledeng/PAM diberi skor 3, sehingga skor total minimum 2 dan maksimum 6.

3. Sarana pembuangan limbah RT dinilai dengan 3 pertanyaan yang meliputi tempat buang air besar, membuang sampah, dan membuang air limbah. Jawaban diberi skor terendah 1 dan tertinggi 3, sehingga total skor minimum 3 dan maksimum 9 .

Kategori kondisi lingkungan tempat tinggal diperoleh berdasarkan gabungan dari total skor kondisi fisik rumah, sumber air, dan sarana pembuangan limbah RT, sehingga total skor minimum 18 dan skor maksium 54.

Data perilaku hidup sehat dinilai melalui 23 pertanyaan tentang kebersihan anggota keluarga, kebiasaan makan keluarga, kebersihan makanan dan kebersihan peralatan makan, kebiasaan olahraga dan kebiasaan tidak merokok dengan pilihan jawaban tidak pernah, kadang-kadang, dan selalu. Jawaban tidak pernah diberi skor 1, kadang-kadang diberi skor 2, dan selalu diberi skor 3, sehingga total skor minimum 23 dan maksimum 69.

Pengkategorian kondisi lingkungan yang meliputi kondisi fisik rumah, sumber air, dan sarana pembuangan limbah RT, serta perilaku hidup sehat berdasarkan interval kelas data dengan perhitungan sebagai berikut (Slamet, 1993):

$$
\begin{aligned}
& \text { Interval kelas }=\frac{\text { range }}{\text { jumlah kelas }} \\
& \text { Range }=\text { skor tertinggi }- \text { skor terendah }
\end{aligned}
$$

Pengkategorian kondisi lingkungan dan perilaku hidup sehat adalah sebagai berikut:

1. Kondisi fisik rumah dikategorikan rendah jika diperoleh skor 13-21, kategori sedang jika diperoleh skor 22-30, dan baik jika diperoleh skor 31-39.

2. Sumber air dikategorikan menjadi rendah jika diperoleh skor 2-3, jika diperoleh skor 4-5, dan baik jika diperoleh skor 6 .

3. Sarana pembuangan limbah RT dikategorikan menjadi rendah dengan skor 4-5, sedang 5-7, dan baik dengan skor 8-9.
4. Kondisi lingkungan tempat tinggal dikategorikan menjadi rendah jika diperoleh skor 18-29, sedang jika diperoleh skor 30-42, dan baik jika diperoleh skor 43-54.

5. Perilaku hidup sehat dikategorikan rendah jika diperoleh skor 23-37, sedang jika diperoleh skor 38-54, dan baik jika diperoleh skor 55-69.

Data konsumsi suplemen dan tanaman obat merupakan konsumsi suplemen dan tanaman obat oleh anggota keluarga dalam satu bulan terakhir. Alasan mengonsumsi suplemen dibedakan menjadi alasan kesehatan, kebugaran dan menambah energi, dan untuk menambah nafsu makan. Tujuan konsumsi tanaman obat dibedakan menjadi tujuan promotif dan kuratif.

Status kesehatan keluarga dilihat berdasarkan ada tidaknya anggota keluarga yang sakit satu bulan terakhir, meliputi jenis penyakit infeksi, lama sakit, dan frekuensi sakit. Variabel yang digunakan dalam uji statistika adalah rata-rata lama sakit anggota keluarga dan prevalensi penyakit infeksi dalam keluarga. Hubungan antar variabel yaitu karakteristik keluarga, kondisi lingkungan, perilaku hidup sehat, dan status kesehatan digunakan uji korelasi Rank Spearman.

\section{HASIL DAN PEMBAHASAN}

\section{Karakteristik Keluarga}

Seluruh ibu bekerja sebagai pemetik teh, yang membedakan adalah lama telah bekerja dan status pekerjaan ibu. Lebih dari separuh ibu telah bekerja menjadi pemetik teh sekitar 1 sampai 14 tahun dan berstatus sebagai pemetik lepas.

Sebagian besar ayah (77.4\%) dan ibu (77.2\%) termasuk usia dewasa madya atau berumur antara 30 - 49 tahun, dengan tingkat pendidikan lebih dari separuh ayah (64.3\%) dan ibu (73.9\%) adalah tamat SD dengan lama pendidikan 6 tahun. Lebih dari separuh ayah (62\%) bekerja di perkebunan. Berdasarkan batas kemiskinan Propinsi Jawa Barat (BPS, 2006), sebesar $63 \%$ keluarga termasuk keluarga miskin. Lebih dari separuh jumlah keluarga (53.3\%) memiliki jumlah anggota keluarga 5 sampai 7 orang dan termasuk dalam keluarga sedang.

\section{Kondisi Lingkungan Tempat Tinggal}

\section{Kondisi fisik rumah}

Semua rumah yang ditempati keluarga adalah milik perkebunan dengan rata-rata luas 
rumah $30.23 \mathrm{~m}^{2}$. Luas rumah bila dibandingkan dengan jumlah penghuni (luas ruangan per orang) akan menggambarkan tingkat kepadatan suatu rumah. Menurut Sukarni (1994), luas ruangan per orang yang baik adalah $>10 \mathrm{~m}^{2}$ / orang, cukup antara 7-10 $\mathrm{m}^{2} /$ orang, dan yang kurang adalah $<7 \mathrm{~m}^{2} /$ orang. Sebesar $57.6 \% \mathrm{me}-$ miliki luas ruangan per orang dengan kategori kurang $\left(<7 \mathrm{~m}^{2} /\right.$ orang) (Tabel 1$)$.

Tabel 1. Sebaran Keluarga berdasarkan Kondisi Fisik Rumah

\begin{tabular}{|c|c|c|}
\hline Kondisi fisik rumah & $\mathbf{n}$ & $\%$ \\
\hline \multicolumn{3}{|l|}{ Jenis lantai rumah } \\
\hline a. Tanah dan plester/tanah dan panggung & 31 & 33.7 \\
\hline b. Plester/Panggung & 61 & 66.3 \\
\hline \multicolumn{3}{|l|}{ Dinding } \\
\hline a. Bambu/triplek/kayu & 80 & 87 \\
\hline b. Bambu/triplek/kayu dan tembok & 2 & 2.2 \\
\hline c. Tembok & 10 & 10.9 \\
\hline \multicolumn{3}{|l|}{ Atap } \\
\hline a. Seng & 6 & 6.5 \\
\hline b. Genteng & 86 & 93.5 \\
\hline \multicolumn{3}{|l|}{ Ventilasi rumah } \\
\hline a. Tidak ada & 78 & 84.8 \\
\hline b. Ada, tertutup sehingga udara tidak bisa & & \\
\hline keluar masuk & 13 & 14.1 \\
\hline $\begin{array}{l}\text { c. Ada, terbuka sehingga udara bisa keluar } \\
\text { masuk }\end{array}$ & 1 & 1.1 \\
\hline \multicolumn{3}{|l|}{ Jendela rumah } \\
\hline a. Ada, hanya di beberapa ruangan & 84 & 91.3 \\
\hline b. Ada, hampir di seluruh ruangan & 8 & 8.7 \\
\hline \multicolumn{3}{|l|}{ Sinar matahari di pagi/siang hari } \\
\hline a. Masuk hanya di beberapa ruangan & 84 & 91.3 \\
\hline b. Masuk hampir di seluruh ruangan & 8 & 8.7 \\
\hline \multicolumn{3}{|l|}{ Kepemilikan kamar mandi } \\
\hline a. Tidak & 54 & 58.7 \\
\hline b. Ya & 38 & 41.3 \\
\hline \multicolumn{3}{|l|}{ Kondisi kamar mandi } \\
\hline a. Kotor & 86 & 93.5 \\
\hline b. Bersih & 6 & 6.5 \\
\hline \multicolumn{3}{|l|}{ Kepemilikan jamban } \\
\hline a. Tidak & 84 & 91.3 \\
\hline b. Ya & 8 & 8.7 \\
\hline \multicolumn{3}{|l|}{ Kepemilikan saluran pembuangan air limbah } \\
\hline a. Tidak & 54 & 58.7 \\
\hline b. Ya & 38 & 41.3 \\
\hline \multicolumn{3}{|l|}{ Keberadaan kandang ternak } \\
\hline a. ada, $<10 \mathrm{~m}$ dari rumah & 13 & 14.1 \\
\hline b. ada, $\geq 10 \mathrm{~m}$ dari rumah & 6 & 6.5 \\
\hline c. Tidak ada & 73 & 79.3 \\
\hline \multicolumn{3}{|l|}{ Luas ruangan per orang } \\
\hline a. Kurang (<7 m²/orang) & 53 & 57.6 \\
\hline b. Cukup baik (7-10 $\mathrm{m}^{2} /$ orang) & 27 & 29.3 \\
\hline c. Baik (>10 $\mathrm{m}^{2} /$ orang) & 12 & 13 \\
\hline
\end{tabular}

Lebih dari separuh jumlah keluarga (68.5\%) memiliki kondisi fisik rumah dengan kategori sedang, sedangkan sebesar $22.8 \%$ dan 7.6\% masing-masing berada pada kategori rendah dan baik. Keluarga dengan kondisi fisik ru- mahnya rendah disebabkan oleh jenis dinding bilik, kondisi kamar mandi dan ventilasi yang kurang memadai, tidak adanya jamban, dan luas ruangan per orang yang kurang.

\section{Sumber Air}

Sumber air sebagian besar keluarga $(94.6 \%)$ termasuk dalam kategori sedang. Sumber air yang digunakan oleh keluarga meliputi sumber air minum dan air bersih untuk keperluan mandi dan mencuci. Masih ditemukan keluarga (13\%) yang menggunakan air sungai sebagai sumber air bersih untuk mencuci dan mandi, namun sebagian besar berasal dari sumur/mata air (Tabel 2). Menurut Notoatmodjo (2003), untuk daerah pedesaan, air minum yang berasal dari mata air dan sumur dapat diterima sebagai air yang sehat jika tidak tercemar oleh kotoran, terutama kotoran manusia dan kotoran binatang.

Tabel 2. Sebaran Keluarga berdasarkan Sumber Air

\begin{tabular}{lcc}
\hline \multicolumn{1}{c}{ Sumber air } & n & $\%$ \\
\hline Sumber air minum & & \\
\hline a. Air sungai/air hujan & 0 & 0 \\
b. Sumur /mata air & 65 & 70.7 \\
$\begin{array}{l}\text { c. Ledeng/PAM } \\
\text { Sumber air bersih }\end{array}$ & 27 & 29.3 \\
a. Air sungai/air hujan & & \\
b. Sumur /mata air & 12 & 13 \\
c. Ledeng/PAM & 75 & 81.5 \\
\hline
\end{tabular}

\section{Sarana Pembuangan Limbah Rumah tangga}

Sebagian besar keluarga (93.5\%) biasa buang hajat di empang dan selokan kecil yang sengaja dibuat sebagai jamban untuk membuang kotoran manusia. Sebagian besar keluarga (93.5\%) membuang sampah akhir di pekarangan/lubang terbuka/sungai. Sebesar $51.1 \%$ keluarga membuang air limbahnya melalui saluran air/pembuangan/got terbuka (Tabel 3).

Tabel 3. Sebaran Keluarga berdasarkan Sarana Pembuangan Limbah RT

\begin{tabular}{|c|c|c|}
\hline Sarana pembuangan & $\mathbf{n}$ & $\%$ \\
\hline \multicolumn{3}{|l|}{ Sarana keluarga biasa buang hajat } \\
\hline a. Empang/kolam/selokan & 86 & 93.5 \\
\hline b. Jamban pribadi dengan septic tank & 6 & 6.5 \\
\hline \multicolumn{3}{|l|}{ Sarana pembuangan sampah keluarga } \\
\hline a. Pekarangan/lubang terbuka/sungai & 86 & 93.5 \\
\hline b. Tempat sampah tertutup/ TPS & 6 & 6.5 \\
\hline \multicolumn{3}{|l|}{ Sarana keluarga buang air limbah } \\
\hline a. Pekarangan/kolam & 22 & 23.9 \\
\hline b. Saluran air/pembuangan/got terbuka & 47 & 51.1 \\
\hline c. Saluran air/pembuangan/got tertutup & 23 & 25 \\
\hline
\end{tabular}


Lebih dari separuh keluarga (69.6\%) sarana pembuangannnya berada dalam kategori rendah. Hal ini menunjukkan bahwa masih banyak keluarga yang menggunakan sarana pembuangan yang tidak memenuhi persyaratan kesehatan.

Kondisi lingkungan tempat tinggal keluarga dinilai berdasarkan gabungan skor kondisi fisik rumah, sumber air serta sarana pembuangan limbah RT. Persentase terbesar keluarga (73.9\%) memiliki kondisi lingkungan tempat tinggal dengan kategori sedang. Keluarga yang mempunyai kondisi lingkungan dengan kategori baik masih sangat sedikit, hanya sebesar $6.5 \%$.

\section{Perilaku Hidup Sehat}

Perilaku hidup sehat merupakan perilaku yang berkaitan dengan upaya seseorang untuk mempertahankan dan meningkatkan kesehatannya (Notoatmodjo, 2007). Lebih dari separuh keluarga $(73.9 \%)$ perilaku hidup sehatnya termasuk dalam kategori baik, 26.1\% keluarga dalam kategori sedang, dan tidak ditemukan keluarga yang memiliki perilaku hidup sehat dengan kategori rendah. Sebaran keluarga berdasarkan perilaku hidup sehat selengkapnya dapat dilihat pada Gambar 1.

\section{$\underline{\text { Status Kesehatan }}$}

Sebagian besar keluarga $(87 \%)$ termasuk dalam kategori tidak sehat karena terdapat anggota keluarga yang sakit dalam satu bulan terakhir. Penyakit yang paling banyak ditemukan pada sebagian besar keluarga yaitu penyakit infeksi.

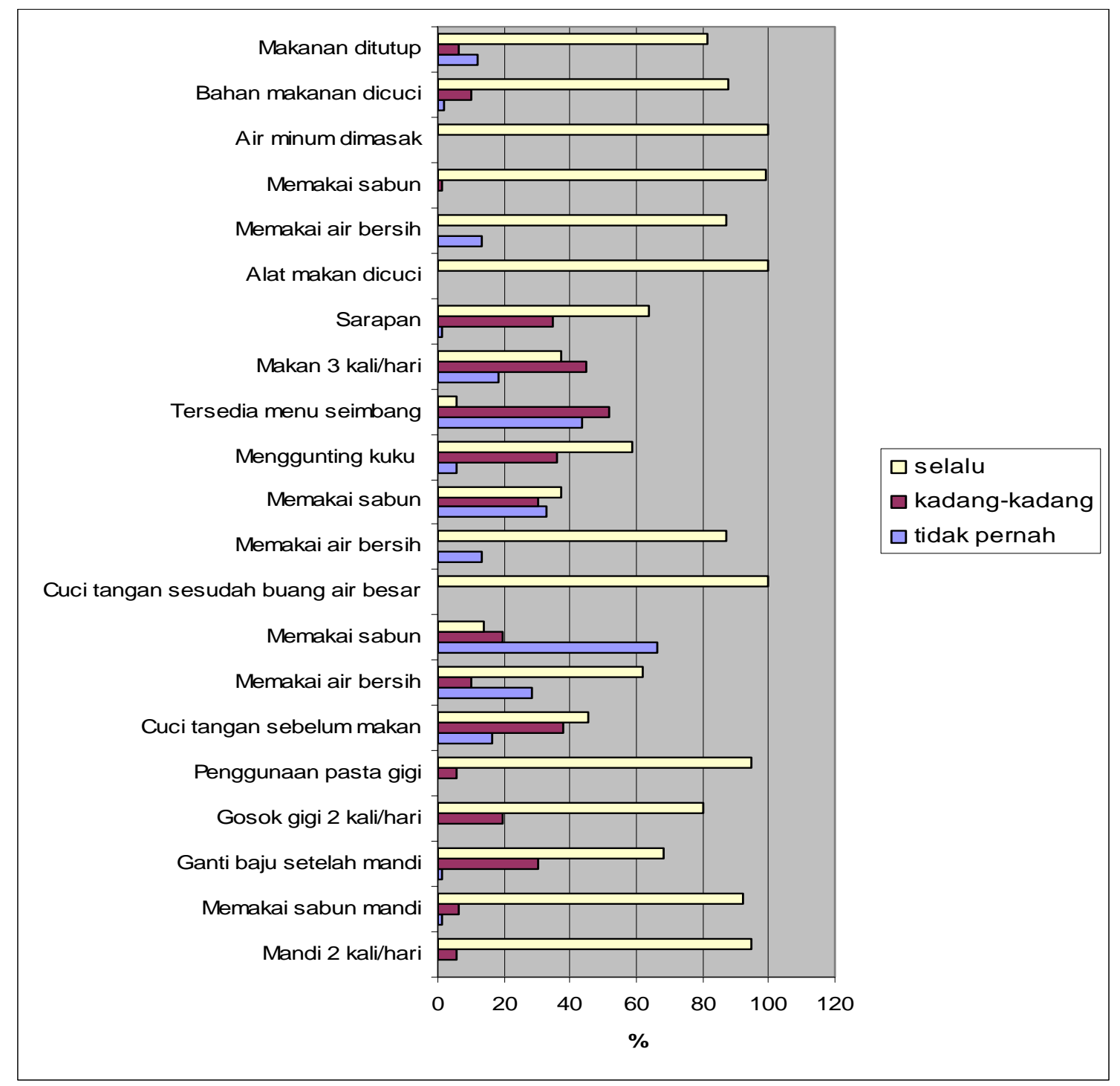

Gambar 1. Sebaran Keluarga berdasarkan Perilaku Hidup Sehat 
Penyakit infeksi adalah penyakit yang disebabkan bakteri, virus, jamur, protozoa, cacing, dan alga (Shulman et al., 1994; Entjang, 2000). Gejala/tanda/jenis penyakit infeksi yang banyak diderita angggota keluarga contoh dalam satu bulan terakhir yaitu panas/deman dengan persentase sebesar 5.3\%, ISPA (infeksi saluran pernapasan akut) dengan prevalensi $23.9 \%$, infeksi saluran pencernaan $3.4 \%$, penyakit kulit $0.7 \%$, dan hepatitis $0.2 \%$. (Tabel 4).

Tabel 4. Gejala/Tanda/Jenis Penyakit Infeksi yang Diderita Anggota Keluarga*)

\begin{tabular}{lcc}
\hline $\begin{array}{c}\text { Gejala/tanda/jenis penyakit } \\
\text { infeksi }\end{array}$ & $\mathbf{n}$ & $\%$ \\
\hline Panas/demam & 23 & 5.3 \\
ISPA & 104 & 23.9 \\
Infeksi saluran pencernaan & 15 & 3.4 \\
Penyakit kulit & 3 & 0.7 \\
Hepatitis & 1 & 0.2 \\
\hline
\end{tabular}

Keterangan: *) Total $n=436$

Berdasarkan hasil penelitian, infeksi saluran pernafasan akut (ISPA) merupakan penyakit infeksi dengan prevalensi terbesar. Menurut Sukarni (1994), masih tingginya angka kesakitan akibat ISPA di Indonesia, disebabkan masih terbatasnya penyediaan air bersih, sarana pembuangan sampah dan air limbah, dan lingkungan perumahan yang kotor (kurang sehat). Selain itu, penyakit ISPA merupakan penyakit yang mudah ditularkan melalui udara.

Anggota keluarga yang paling rentan terkena penyakit yaitu balita. Sesuai dengan pendapat Soekirman (2000), bahwa salah satu golongan usia yang rentan terhadap risiko terserang penyakit adalah anak di bawah usia 5 tahun (balita). Jumlah total balita dari 92 keluarga adalah 108 balita, dan sebesar $68.5 \%$ balita pernah sakit dalam satu bulan terakhir. Prevalensi penyakit infeksi terbesar pada balita yaitu ISPA sebesar 53.7\% (Tabel 5).

Tabel 5. Gejala/Tanda/Jenis Penyakit Infeksi yang Diderita Balita*)

\begin{tabular}{lcc}
\hline $\begin{array}{c}\text { Gejala/tanda/jenis penyakit } \\
\text { infeksi }\end{array}$ & $\mathbf{n}$ & $\%$ \\
\hline Panas/demam & 14 & 13 \\
ISPA & 58 & 53.7 \\
Infeksi saluran pencernaan & 5 & 4.6 \\
Penyakit kulit & 2 & 1.9 \\
\hline
\end{tabular}

Keterangan: *) Total $n=108$

Menurut Hardjono (2000), salah satu indikator status kesehatan keluarga yaitu status kesehatan balita. Hasil analisis menunjukkan bahwa kejadian sakit pada balita berhubungan dengan prevalensi penyakit infeksi pada kelu- arga $(r=0.499, p<0.01)$. Hal ini menunjukkan bahwa besarnya prevalensi penyakit dalam keluarga dapat digunakan sebagai indikator status kesehatan keluarga.

Lama sakit lebih dari separuh (56.8\%) jumlah anggota keluarga yang sakit adalah 4-7 hari dan sebagian besar anggota keluarga (85.6\%) mengalami sakit dengan frekuensi 1 kali dalam sebulan.

Lama sakit anggota keluarga berhubungan dengan umur anggota keluarga ( $r=-0.265$, $\mathrm{p}<0.01)$. Frekuensi sakit anggota keluarga juga berhubungan dengan umur anggota keluarga $(r=-0.293, p<0.01)$. Hal ini berarti bahwa semakin rendah umur anggota keluarga, maka semakin lama sakitnya dan lebih sering atau mudah mengalami sakit. Hasil uji korelasi tersebut sesuai dengan temuan bahwa anggota keluarga yang mengalami sakit lebih lama dan mengalami sakit lebih dari satu kali dalam sebulan adalah balita.

Pernyataan Skinner (1938) yang dikutip dalam Notoatmodjo (2007) menyebutkan bahwa perilaku pencarian pengobatan merupakan salah satu perilaku yang berhubungan dengan kesehatan. Berdasarkan Tabel 6 terlihat bahwa pelayanan kesehatan yang banyak dimanfaatkan dalam tindakan pengobatan anggota keluarga ketika sakit adalah klinik kebun (33.1\%) dan puskesmas (24.5\%). Akan tetapi, upaya pengobatan sendiri tanpa memanfaatkan pelayanan kesehatan yaitu dengan membeli obat di warung masih banyak dilakukan ketika anggota keluarga sakit (26.6\%).

Tabel 6. Sebaran Anggota Keluarga yang Sakit berdasarkan Tindakan Pengobatan

\begin{tabular}{lcc}
\hline \multicolumn{1}{c}{ Tindakan pengobatan } & $\mathbf{n}$ & $\%$ \\
\hline Mantri & 5 & 3.6 \\
Bidan & 1 & 0.7 \\
Dokter & 9 & 6.5 \\
Klinik kebun & 46 & 33.1 \\
Puskesmas & 34 & 24.5 \\
Beli obat warung & 37 & 26.6 \\
Obat tradisional & 2 & 1.4 \\
Tidak berobat & 5 & 3.6 \\
\multicolumn{1}{c}{ J umlah } & 139 & 100 \\
\hline \multicolumn{2}{c}{}
\end{tabular}

\section{Faktor - faktor yang berhubungan dengan Kondisi Lingkungan, Perilaku Hidup Sehat dan Status Kesehatan Keluarga}

Kondisi lingkungan lebih dipengaruhi oleh pendapatan keluarga dan besar keluarga. Hal ini sesuai dengan hasil analisis, bahwa pendapatan berhubungan positif nyata dengan kondisi lingkungan $(r=0.343, p<0.01)$, sedang- 
kan besar keluarga berhubungan negatif dengan kondisi lingkungan $(r=-0.217, p<0.05)$.

Hasil analisis menunjukkan bahwa pendapatan keluarga berhubungan positif dengan lama sakit anggota keluarga yang merupakan indikator kesehatan keluarga $(r=-0.232$, $p<0.05)$. Hal ini sesuai dengan pendapat Lumenta (1989) bahwa pendapatan berhubungan dengan upaya pemeliharaan dan peningkatan kesehatan serta kemampuan dalam memanfaatkan fasilitas pelayanan kesehatan dalam memperoleh kesembuhan ketika sedang sakit. Keluarga dengan pendapatan rendah cenderung kesulitan dalam mencari pengobatan dan memiliki keterbatasan dalam mengakses fasilitas pelayanan kesehatan.

Kondisi lingkungan yang berhubungan dengan penyakit infeksi adalah sumber air bersih yang digambarkan dengan hubungan negatif antara sumber air bersih dengan prevalensi penyakit hepatitis $(r=-0.260, p<0.05)$. Hasil analisis juga menunjukkan bahwa sumber air bersih untuk mencuci/mandi berhubungan negatif dengan prevalensi penyakit ISPA $(r=-0,223$, $p<0.05)$ dan prevalen- si penyakit hepatitis $(r=-$ $0.234, p<0.05)$. Hal ini berarti semakin baik sumber air bersih maka prevalensi penyakit ISPA dan hepatitis akan semakin kecil.

Indikator perilaku hidup sehat yang berhubungan dengan penyakit infeksi adalah pemakaian air bersih untuk mencuci tangan setelah buang air besar berhubungan dengan prevalensi penyakit ISPA $(r=-0.274, p<0.01)$ dan prevalensi penyakit hepatitis $(r=-0.271$, $\mathrm{p}<0.01)$. Menurut Slamet (1996) bahwa air berperan besar dalam terjadinya penyakit menular. Apabila terdapat mikroorganisme yang masuk ke dalam sumber air yang digunakan oleh masyarakat untuk memenuhi kebutuhan sehari-hari, maka dapat menjadi sumber penularan penyakit menular.

\section{KESIMPULAN}

Sebagian besar ayah dan ibu berada pada rentang usia 30-49 tahun (dewasa madya). Lebih dari separuh ayah dan ibu memiliki tingkat pendidikan tamat SD dan lebih dari separuh keluarga termasuk ke dalam kategori keluarga miskin. Persentase terbesar keluarga merupakan keluarga berukuran sedang dengan jumlah anggota keluarga antara 5-7 orang.

Rumah yang ditempati oleh keluarga seluruhnya adalah milik perkebunan dengan luas berkisar antara $13 \mathrm{~m}^{2}$ sampai $72,0 \mathrm{~m}^{2}$, dengan rata-rata $30.2 \mathrm{~m}^{2}$. Lebih dari separuh keluarga memiliki kondisi fisik rumah dengan kategori sedang dan masih ditemukan $22.8 \%$ keluarga dengan kategori rendah. Sumber air yang digunakan oleh sebagian besar keluarga berasal dari sumur/mata air. Sebesar 73.9\% keluarga memiliki perilaku hidup sehat yang termasuk dalam kategori baik dan sebesar 26.1\% keluarga memiliki perilaku hidup sehat dengan kategori sedang.

Status kesehatan keluarga dilihat berdasarkan ada tidaknya anggota keluarga yang sakit dan besarnya prevalensi penyakit infeksi dalam keluarga. Sebagian besar keluarga (87\%) termasuk dalam kategori tidak sehat. Gejala/ tanda/jenis penyakit infeksi yang ditemukan dalam satu bulan terakhir yaitu demam dengan persentase $5.3 \%$, ISPA dengan prevalensi sebesar $23.9 \%$, infeksi saluran pencernaan dengan prevalensi $3.4 \%$, penyakit kulit $0.7 \%$, dan hepatitis dengan prevalensi $0.2 \%$.

Faktor yang berhubungan dengan kondisi lingkungan pada keluarga wanita pemetik teh adalah pendapatan keluarga dan besar keluarga. Lama sakit anggota keluarga berhubungan dengan pendapatan keluarga. Aspek kondisi lingkungan yang berhubungan dengan kesehatan keluarga wanita pemetik teh yaitu sumber air yang digunakan keluarga. Prevalensi penyakit hepatitis dan ISPA berhubungan dengan sumber air bersih untuk mandi atau mencuci. Pemakaian air bersih untuk mencuci tangan setelah buang air besar berhubungan dengan prevalensi penyakit ISPA dan hepatitis. Semakin baik sumber air, maka semakin rendah kemungkinan terjadinya suatu penyakit terutama penyakit yang disebabkan oleh air.

\section{UCAPAN TERIMA KASIH}

Terima kasih disampaikan kepada Dr. Euis Sunarti selaku ketua tim peneliti proyek riset yang didanai oleh neys van hoogstraten Foundation (NHF) atas bantuan informasi dan dana publikasi. Bapak Ir. Nandi Suhandi beserta staf PTPN VIII Unit Perkebunan Malabar yang telah memberikan izin tempat untuk melakukan penelitian serta kerja sama yang baik, keluarga Bapak Suhendar atas keramahan yang diberikan, Pemerintahan serta warga Desa Banjarsari Kecamatan Pangalengan atas bantuan yang diberikan, serta teman-teman peneliti atas kerja sama yang baik selama pengambilan data di Pengalengan, dan seluruh pihak yang telah membantu dan mendukung pelaksanaan penelitian ini. 


\section{DAFTAR PUSTAKA}

Basta S, Soekirman, Karyadi D, \& Scrimshaw. 1979. Iron deficiency anemia and productivity of adult males in Indonesia. http: / /www.ajcn.org [20 januari 2008].

BPS. 2002. Statistik Kesejahteraan Rakyat (Welfare Statistics). BPS, Jakarta.

. 2006. Data dan Informasi Kemiskinan Tahun 2005-2006. BPS, Jakarta.

Depkes RI. 1999. Paradigma Sehat Menuju Indonesia Sehat 2010. Depkes, Jakarta.

2005. Kebijakan Anggaran Depkes. http://www.depkes.go.id/.

Bapenas. 2004. Penanggulangan Kemiskinan. http://www.bappenas.go.id/.

Entjang I. 2000. IImu Kesehatan Masyarakat. Cetakan ke-14. Alumni, Bandung.

Hardjono. 2000. Faktor-Faktor yang Mempengaruhi Partisipasi Masyarakat untuk Hidup Sehat. Tesis Program Pascasarjana, $\mathrm{IPB}$, Bogor.

Hurlock EB. 1993. Perkembangan Anak. Jilid ke-2 (Tjandrasa $M$ \& Zarkasih $M$, penerjemah). Erlangga, Jakarta.

Lumenta B. 1989. Penyakit: Citra, Alam, dan Budaya. Penerbit Kanisius, Yogyakarta.

Notoatmodjo S. 2003. Ilmu Kesehatan Masyarakat. Rineka Cipta, Jakarta.

2007. Promosi Kesehatan dan Ilmu Perilaku. Rineka Cipta, Jakarta.
Nur R. 2002. Memprihatinkan Nasib Buruh Perempuan. http://www. kompas.com.

Shulman ST, Phair JP, \& Sommers HM. 1994. Dasar Biologis dan Klinis Penyakit Infeksi. Edisi ke-4 (Wahab S, penerjemah). Gajah Mada University Press, Yogyakarta.

Slamet JS. 1996. Kesehatan Lingkungan. Gajah Mada University Press, Yogyakarta.

Slamet Y. 1993. Analisis Kuantitatif untuk Data Sosial. Dabara Publiser, Solo.

Soekirman. 2000. Ilmu Gizi dan Aplikasinya untuk Keluarga dan Masyarakat. Departemen Pendidikan Nasional, Jakarta.

Subandriyo VU. 1993. Kesehatan Keluarga. Dalam Rustiawan A, Atmodjo SM, Subandriyo VU, \& Effendi YH. Ilmu Kesehatan Masyarakat. Diktat Jurusan Gizi Masyarakat dan Sumberdaya Keluarga, Fakultas Pertanian, IPB, Bogor.

Sukarni M. 1994. Kesehatan Keluarga dan Lingkungan. Penerbit Kanisius, Yogyakarta.

Sunarti E, Roosita K, \& Herawati T. 2007. A Study Of Plantation Women Workers: Socio Economic Status, Family Strength, Food Consumption, And Children Growth And Development. Laporan Kemajuan yang Tidak Dipublikasikan, Fakultas Pertanian, IPB, Bogor.

Wirakusumah ES. 1999. Perencanaan Menu Anemia Gizi Besi. Trubus Agriwidya, Jakarta .

WNPG. 2004. Ketahanan Pangan dan Gizi di Era Otonomi Daerah dan Globalisasi. LIPI, Jakarta. 